\title{
THE DIAGNOSTIC IMPORTANCE OF THE HETEROPHILE ANTIBODY TEST IN LEUKEMIA
}

\author{
By ALAN BERNSTEIN \\ (From the Medical Clinic, the School of Medicine, Johns Hopkins University \\ and Hospital, Baltimore)
}

(Received for publication April 12, 1934)

With the demonstration by Paul and Bunnell (1) of an increased titer of heterophile antibodies in the blood serum of patients suffering from infectious mononucleosis, the heterophile antibody test has been introduced into the field of clinical usefulness. Previous to the observations of these authors in 1932, it had been recognized that the blood of most normal individuals contained, in low concentrations, heterophile antibodies, in the form of agglutinins and hemolysins for sheep red blood cells. Following the administration of horse serum these antibodies appeared in increased titer (Davidsohn (2)). Paul and Bunnell (1) reported four cases of infectious mononucleosis which showed heterophile agglutinins to a markedly increased titer. The essential features of their observations have been confirmed by Rosenthal and Wenkebach (3), Boveri (4), Bunnell (5) and Bernstein (6).

It is the purpose of this report to call attention to the very low titer of heterophile antibodies which exists with great constancy in the blood serum of patients with leukemia, to indicate the value of the heterophile antibody test in some conditions differentiated clinically from leukemias with difficulty, and to correlate the findings with previously known data concerning bacterial antibody responses in leukemias.

\section{METHODS}

The technical details and symbols by which the results are recorded are identical with those described by Bernstein (6) in a previous paper which may be consulted.

\section{Heterophile antibodies in conditions other than leukemia}

In normal individuals, and in patients suffering from a variety of diseases, sheep cell agglutinins may be present in dilutions ranging from 1 to 1 up to 1 to 16 . Occasionally there will be no agglutination even in the 1 to 1 dilution. In a group of over 300 such cases, 30 per. cent showed no agglutination above 1 to 2 while 70 per cent fell in the range from 1 to 4 up to 1 to 16 (6). For purposes of convenience, the range below 1 to 4 
will henceforth be referred to as Zone 1. The interval from 1 to 4 up to 1 to 16 inclusive will be Zone 2, while the distribution above 1 to 16 will be Zone 3. Thirty per cent of the control group, then, fall in Zone 1; 70 per cent in Zone 2. The great majority of cases of infectious mononucleosis as well as many individuals recently treated with horse serum, appear in Zone 3 (Figure 1).

\begin{tabular}{|c|c|c|c|c|c|c|c|}
\hline \multicolumn{4}{|c|}{ Normal } & \multicolumn{4}{|c|}{ Infectious mononucleosis } \\
\hline$\leftarrow 1: 1^{\text {Zone } 1} 1: 2$ & $1: 4$ & $\begin{array}{l}\text { Zone } \\
1: 8\end{array}$ & $1: 16$ & $1: 32$ & $1: 64$ & $\begin{array}{l}\text { Zone } 3 \\
1: 128 \quad 1: 256\end{array}$ & $1: 512 \rightarrow$ \\
\hline Leukemia & & & & Serum & therap & & \\
\hline
\end{tabular}

Fig. 1. Heterophile Antibody Titers under Varjous Circumstances

\section{Heterophile antibodies in diseases which may simulate leukemia}

Under certain circumstances the following diseases may so closely resemble one of the forms of leukemia that clinical differentiation is difficult: acute infections with hyperleukocytosis; miliary tuberculosis; thrombocytopenic purpura; agranulocytic angina; aplastic anemia; erythroleukemia; infectious mononucleosis; Hodgkin's disease; lymphosarcoma; and carcinoma, tuberculosis or syphilis involving lymph glands.

It has already been noted that in infectious mononucleosis heterophile antibodies usually fall in Zone 3. In two or more instances of the rest of the above mentioned maladies except lymphosarcoma, the antibodies are not necessarily confined to Zone 1 , but may fall in Zone 2 as well. Unfortunately only one case of lymphosarcoma has been available for study so that no valid conclusions can be drawn concerning it.

\section{Heterophile antibodies in leukemia}

In all the forms of leukemia that were studied, with the exception of one case, heterophile antibodies were limited to Zone 1 (Table I). The single instance in which the agglutinins were encountered in Zone 2 was found, at autopsy, to represent a chronic myeloid leukemia complicated by an osteomyelitis of the jaw and a healed bacterial endocarditis of the aortic valve (Case 13, Table I). In the remaining twenty cases which included acute and chronic forms of lymphoid and monocytic, as well as chronic myeloid leukemia, heterophile antibodies were uniformly low. This rule holds true irrespective of whether or not the patient has received therapy of any sort, including radium or irradiation. For example Case 16 (Table I) when first seen, had a leukocyte count of 400,000. Her heterophile agglutinins were 1 to 2 . Five weeks later, after intensive $x$-ray therapy, her 
TABLE I

Heterophile antibody titers in twenty-one cases of leukemia, both treated and untreated

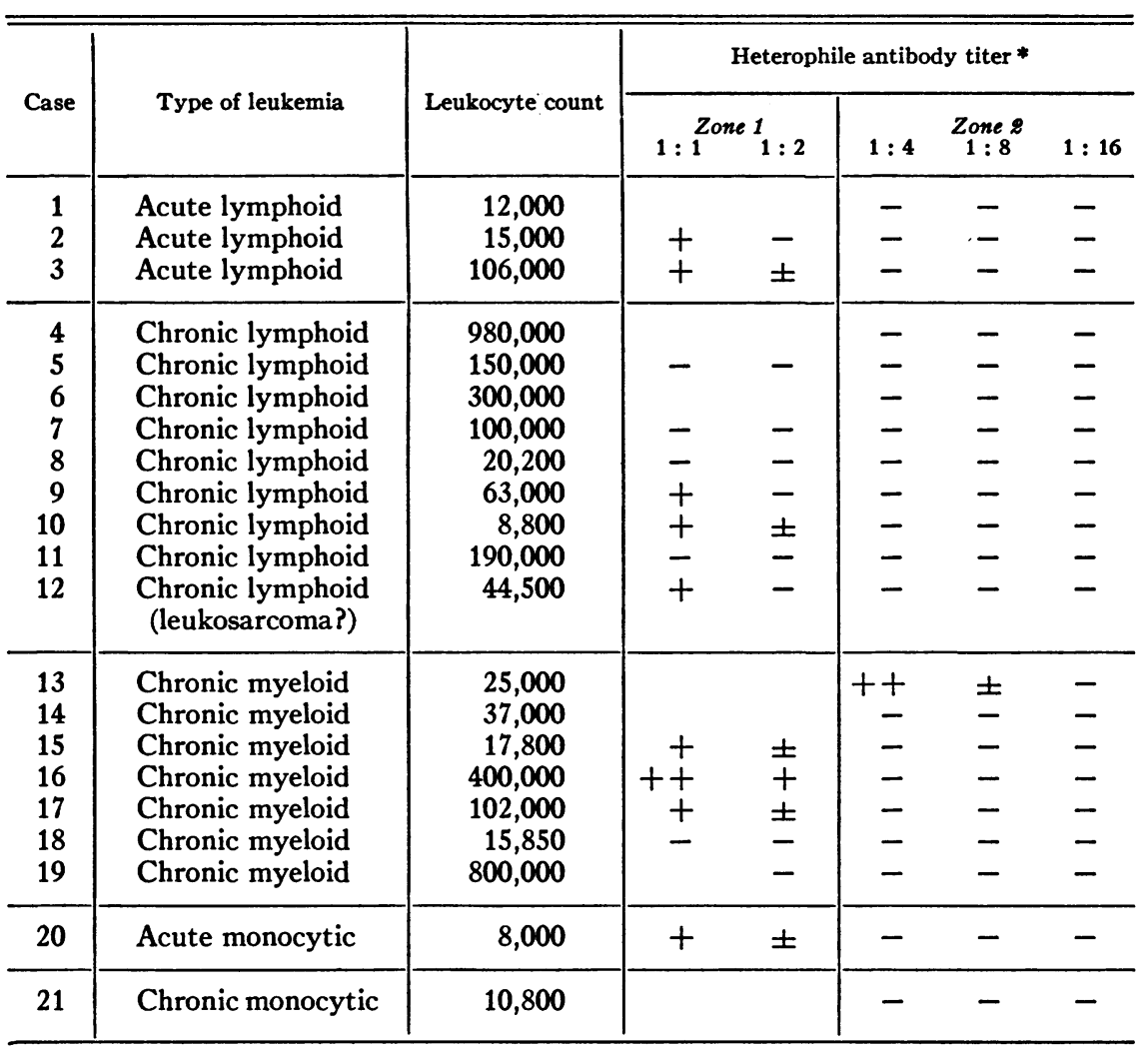

* Blank spaces indicate that no determinations were carried out at these dilutions.

white blood cell count had fallen to 10,000 but the heterophile agglutinins remained 1 to 2 .

Instances in which heterophile antibody determinations proved helpful in clinically confusing conditions

The relevant details of two cases in which doubt existed as to whether or not a leukemia was present, will be presented. In both of these, the conclusions derived in part from heterophile agglutinin determinations were in accord with the diagnosis based on autopsy or biopsy.

Case 22. S. F., a white male, tire builder, aged 36 years, was admitted to the Johns Hopkins Hospital on March 24, 1933 complaining of shortness of breath and weakness. For seven years preceding the onset of the present illness he had worked as an automobile tire builder in which capacity he was constantly exposed to the fumes of benzol. 
Early in January, 1933 he developed an acute respiratory infection with a chill, fever, cough and soreness in the chest. From this attack he recovered within a week but from that time on he became weak, suffering from sweats and dyspnoea on exertion.

On admission his temperature was $103^{\circ} \mathrm{F}$. He appeared chronically ill. There was a waxen pallor of the skin and the mucous membranes were almost colorless. In the mouth and over the upper trunk were numerous petechiae. There was slight general glandular enlargement. Neither spleen nor liver could be felt.

The patient's course was steadily downhill. It was characterized by irregular fever, various hemorrhagic phenomena and progressive weakness. He died on May 4, 1933.

Examination of the blood at the time of admission showed a depression of all elements with an increase of young myeloid cells. Red blood cells were $3,530,000$; hemoglobin was 40 per cent; the leukocytes were 3,800 ; platelets were 42,000 . There was prolongation of the bleeding time, clotting time and the clot retraction. A differential count showed myeloblasts 4 per cent; myelocytes 35 per cent; juvenile neutrophils 19 per cent; segmented neutrophils 5 per cent; basophils 2 per cent; young lymphocytes 25 per cent; adult lymphocytes 10 per cent. Repeated blood cultures were sterile.

The difficulties in diagnosis were obvious. The problem was tersely stated by one observer as follows: "A most confusing case! The story suggests, among other things, benzol poisoning. The blood picture indicates rather an acute myeloid leukemia (aleukemic). The clinical picture might be either of these. It seems to me most likely that this is a case of acute myeloid leukemia (aleukemic) in a man who happens to have been exposed to benzol."

At autopsy there were petechial hemorrhages throughout the organs but no evidence of cellular infiltration. The bone marrow was hyperplastic but full of abnormal young white blood cells. The hyperplasia was considered to have developed because the patient had been removed from benzol for some months before his death, which gave the bone marrow opportunity to attempt to regenerate. The pathological diagnosis was aplastic anemia due to benzol poisoning.

During the patient's stay in the hospital three determinations of heterophile antibodies in his blood serum were carried out. The titer varied between 1 to 8 and 1 to 16 , evidence according to previous observations that the disease was not a leukemia.

Case 10.1 A. M., a white female, housewife, aged 30 years, was admitted to the Union Memorial Hospital on November 4, 1933 complaining of fever and weakness. The illness had begun in March 1932 with pains in the extremities. Examination of the blood in November 1932 showed no anemia but there was revealed a leukocytosis of 21,600 of which 76 per cent were lymphocytes. At that time her general condition was so excellent that it seemed unlikely that she could be suffering from leukemia. She was given Fowler's solution under which therapy there was subjective improvement. However, she developed progressive anemia, became gradually weaker and finally hospitalization was necessary.

On admission to the hospital in November 1933 her temperature was $101^{\circ} \mathrm{F}$. She was notably pale and weak. There was no glandular enlargement but the spleen was moderately increased in size. Examination of the blood showed 2,700,000 red blood cells, hemoglobin 50 per cent, and 8,800 white blood cells of

${ }^{1}$ For the privilege of quoting the data in this case I am indebted to Dr. John L. Dorsey. 
which 25 per cent were polymorphonuclear neutrophils, 74 per cent small lymphocytes and 1 per cent monocytes.

The course of her disease was characterized by fever and continued bone pains. Leukocyte counts varied between 8,000 and 22,000 but were usually below 10,000. She was treated with transfusions, liver extract, pentnucleotide and irradiation; all to no avail. An axillary lymph node, removed on November 6, showed an increase of lymphocytes but was not typical of leukemia. Although an aleukemic lymphoid leukemia seemed the most probable diagnosis, splenectomy was carried out on November 14 with the hope that an obscure infection or an atypical Banti's disease might be improved by this measure. The microscopic sections of the spleen showed unmistakable signs of lymphoid leukemia. The patient failed gradually so that in April 1934 she was close to death, with a hemoglobin of 10 per cent.

At the time of splenectomy, sheep cell agglutinins in her blood serum were 1 to 2 , a value compatible with leukemia.

\section{The effect of horse serum upon the titer of heterophile antibodies in leukemia}

In normal individuals the injection of horse serum will elicit, with rare exceptions, an increase in the concentration of sheep cell agglutinins (2). It was deemed proper, therefore, to determine whether or not a patient with leukemia would react similarly. A patient suffering from chronic lymphoid leukemia (Case 9, Table I), was injected intravenously with two $10 \mathrm{cc}$. doses of horse serum on successive days. Preliminary skin tests proved him not to be sensitive to the material employed. The heterophile agglutinin titer was measured at frequent intervals (Table II).

TABLE II

Effect of intravenous injection of horse serum upon the heterophile antibody titer of the blood serum of a patient with chronic lymphoid leukemia. (Case 9, Table I)

\begin{tabular}{|c|c|c|c|c|c|}
\hline Date & $\begin{array}{l}\text { Amount of serum } \\
\text { administered }\end{array}$ & Days after serum & \multicolumn{3}{|c|}{ Heterophile antibody titer } \\
\hline $\begin{array}{l}1983 \\
\text { September } 15 \ldots \ldots \ldots \ldots \\
\text { September } 20 \ldots \ldots \ldots \ldots \\
\text { September } 21 \ldots \ldots \ldots \ldots \\
\text { September } 23 \ldots \ldots \ldots \ldots \ldots \\
\text { September } 25 \ldots \ldots \ldots \ldots \ldots \\
\text { September } 26 \ldots \ldots \ldots \ldots \\
\text { September } 28 \ldots \ldots \ldots \ldots \ldots \\
\text { October } 3 \ldots \ldots \ldots \ldots \ldots\end{array}$ & $\begin{array}{l}10 \\
10\end{array}$ & $\begin{array}{r}1 \\
3 \\
5 \\
6 \\
8 \\
13\end{array}$ & $\begin{array}{l}1: 1 \\
+ \\
+ \\
- \\
+ \\
+\end{array}$ & $\begin{array}{l}1: 2 \\
- \\
- \\
- \\
- \\
-\end{array}$ & $\begin{array}{l}1: 4 \\
- \\
- \\
- \\
- \\
-\end{array}$ \\
\hline
\end{tabular}

The concentration of sheep cell agglutinins did not show any significant variation from the original value over a period of time in which, in a normal - individual, the heterophile antibody titer would have increased.

This same experiment was repeated with a second individual (Case 12, Table I). This was a patient with the hematological findings of lymphoid 
leukemia who in addition had several large abdominal masses, as well as general glandular enlargement, a picture which was considered to conform rather to leukosarcoma than leukemia. An initial one plus heterophile agglutinin titer of 1 to 1 rose to plus minus at 1 to 4 on the eighteenth day after the injection of horse serum. Such an increase is less both in degree and extent than is encountered in normal individuals treated with horse serum. There was no evidence of serum disease in either of the two patients and it is of passing interest to note that the leukocyte counts, during the period of observation, showed no more than the expected oscillations.

\section{DISCUSSION'}

Heterophile antibodies in the sera of patients suffering from leukemia are present in low titer. In twenty-one cases of leukemia, a group that embraced lymphoid, myeloid and monocytic types, sheep cell agglutinins were confined to Zone 1 with the exception of one case of chronic myeloid leukemia. In this respect all types of leukemia behave essentially the same. However, in various other diseases which may simulate leukemias, heterophile antibodies were distributed normally in Zones 1 and 2. As an aid in differential diagnosis, this peculiarity of leukemic serum is of definite value. With heterophile agglutinins present in Zone 2 one can conclude with some assurance that the patient whose serum is being tested is not suffering from a leukemia. With the agglutinins confined to Zone 1 the unknown serum may or may not indicate a leukemia. The test gives only negative evidence. By its use a leukemia can probably be ruled out but it will not definitely establish the existence of a leukemia. Case 22 is an example wherein even negative evidence is of importance. The presence of sheep cell agglutinins in Zone 2 suggested that the disease process was not leukemia, a conclusion which was subsequently substantiated by pathological examination. In Case 10 one could only say that the agglutinin titer was compatible with leukemia.

That the mechanism whereby antibodies are formed is disturbed in leukemia has been recognized. In 1914 Moreschi (7) obtained little or no agglutinin response to the injection of typhoid vaccine in eight cases of leukemia. For this observation he offered two possible explanations: that the abnormal leukocytes circulating in the blood stream destroyed the antigen; or that the antibody forming ability of the bone marrow was suppressed by the leukemic process. In the same year Rotky (8) injected a strain of vibrios, to which patients with various diseases responded with agglutinins, into two patients with leukemia. Here again no agglutinins were elicited. He suggested a possible relationship between the inadequate antibody response in leukemia and the susceptibility of patients suffering from this disease, to infections. Hickling and Sutliff (9) studied a case of lobar pneumonia occurring in a man with lymphoid leukemia. Although the patient recovered from the acute infection, no agglutinins 
for pneumococci were demonstrable in his blood during convalescence. The absence of agglutinins may be encountered, however, in an otherwise normal person with lobar pneumonia.

In some of their manifestations leukemias have the characteristics of invasive tumors. It is of interest, then, to note that in patients with cancer there was no depression of heterophile antibodies. Sheep cell agglutinins in several cases of carcinoma originating in the pancreas, as well as in one instance of a hypernephroma with multiple skeletal metastases, were normally distributed in Zones 1 and 2.

\section{SUM MARY}

Heterophile agglutinins in the blood sera of twenty-one patients with leukemia were confined to low titers: less than 1 to 4 , in twenty instances. In most of the conditions simulating leukemia, heterophile agglutinins were found over a wider distribution of titers up to 1 to 16 . Two clinical histories are given as examples of instances in which this differential point was of assistance in arriving at a diagnosis.

Intravenous administration of horse serum which, in a normal person, elicits an increase in the concentration of heterophile antibodies, failed, in one case of lymphoid leukemia, to raise the heterophile antibody titer. In a second case of probable leukosarcoma, horse serum brought about a minimal increase of sheep cell agglutinins. Neither of these patients developed serum disease.

The restriction of heterophile antibody concentrations in leukemia to low titers is in accord with previously known immunological characteristics of individuals with this disease.

\section{BIBLIOGRAPHY}

1. Paul, J. R., and Bunnell, W. W., The presence of heterophile antibodies in infectious mononucleosis. Am. J. M. Sc., 1932, 183, 90.

2. Davidsohn, I., Further studies on heterophilic antibodies in serum sickness. J. Immunol., 1930, 18, 31.

3. Rosenthal, N., and Wenkebach, G., Die Bedeutung der Heterophilen Antikörperreaktion für die Diagnose der Infektiösen Mononucleose. Klin. Wchnschr., 1933, 12, 499.

4. Boveri, R., Uber das Vorkommen Heterophiler Antikörper bei Lymphoidzelliger Angina. Klin. Wchnschr., 1933, 12, 666.

5. Bunnell, W. W., A diagnostic test for infectious mononucleosis. Am. J. M. Sc., 1933, 186, 346.

6. Bernstein, A., Antibody responses in infectious mononucleosis. J. Clin. Invest., 1934, 13, 419.

7. Moreschi, C., Ueber antigene und pyrogene Wirkung des Typhusbacillus bei leukämischen Kranken. Ztschr. f. Immunitatsforsch. u. exper. Therap., 1914, Orig., 21, 410.

8. Rotky, H., Über die Fähigkeit von Leukämikern Antikörper zu erzeugen. Zentralbl. f. inn. Med., 1914, 35, 953.

9. Hickling, R. A., and Sutliff, W. D., Pneumonia in a case of chronic lymphatic leukemia. Am. J. M. Sc., 1928, 175, 224. 